DOI https://doi.org/10.32841/2409-1154.2021.48-2.32

Kruk A. A.,

Ph.D. in Philology,

Senior Lecturer at the Department of Foreign Languages

Kamianets-Podilskyi Ivan Ohiienko National University

\title{
CHARACTER TYPIFICATION IN THE PROSE OF T. HARDY AND I. NECHUI-LEVYTSKYI
}

\begin{abstract}
Summary. The article reveals a set of psychological properties that make up the images of literary characters on the material of prose works "Jude the Obscure" (T. Hardy) and "Mykola Dzheria" (I. Nechui-Levytskyi). By clarifying the stylistic, genre, compositional, linguistic and figurative features in T. Hardy and I. Nechui-Levytskyi's prose, the author's images of Jude Fawley and Mykola Dzheria as the main characters are outlined, underlying the epic thinking of the second half of the XIX century. Due to the detailed textual analysis the ideological and aesthetic features of artistic images of protagonists are distinguished, and the peculiarities of authors' creative manners are investigated.
\end{abstract}

In general, the features of typification depend on the worldview of writers, including their philosophical, aesthetic, ethical and religious worldviews. Typification is affected by such features as writers' beliefs, principles of knowledge and ideals. The portrait plays a significant role in authors' characterization. Often the appearance of main heroes gives an idea of such character traits as preferences. Sometimes the portrait description acts really as a mirror of the soul. Quite often authors individualize the portraits of their main characters.

Both writers quite aptly use such means of typification as actions, deeds, dialogues, monologues, stories, portraits of their characters. However, in the work of T. Hardy self-characterization plays a major role in the creation of Jude's character. We often learn about thoughts, experiences, character's inner state from monologues, dialogues, as well as from facial expressions, gestures and eye expressions. Regarding the character typification in I. Nechui-Levytskyi's prose, it is noticeable that the author turns to various images, using such artistic details as visual, sound, as well as psychological analysis. Another no less important way of typification in the works of T. Hardy and I. Nechui-Levytskyi is the expression of protagonists' language, the accurate use of vocabulary, cultural traditions and customs inherent to their people.

Accordingly, summarizing everything, it should be noted that each character in this research was outlined with sufficient completeness and individual specificity. Such typification of characters helps to take into account not only the historically determined type of characters' behavior, but also the moral and aesthetic concept of human existence in general.

Key words: psychological analysis, worldview, artistic cognition, description, image.

Problem statement. The character of man is deeply rooted, not immediately obvious and develops over time. The old saying that "actions speak louder than words" is true when it comes to character traits. We learn a lot about a person's character when we observe how this person interacts with the world. According to Natalia Pavlyk, "характер - це сукупність стійких психологічних ознак, що визначають індивідуальну своєрідність і особливості поведінки людини" [1, p. 40]. The author adds that in philosophical, spiritual and religious concepts, character is seen as a system of moral virtues and flaws of the individual [1, p. 40].

Quite often we come across the literary images of a person with his or her own individual features in literary works. The authors describe the behavior of their characters, their attitude to others or to life in general. It is the colorful set of psychological properties that make up the image of literary characters and can be read in the works "Jude the Obscure" by T. Hardy and "Mykola Dzheria" by I. NechuiLevytskyi. That is why the relevance of the article is the need for a comprehensive analysis of T. Hardy's prose, the core of which is the typification of character, and understanding the comparative reflection of his work in I. Nechui-Levytskyi's prose.

Recent research. The topic of character typing in Ukrainian and English literature is studied here within a comparative approach and is correlated on a synchronous plane, which is the scientific novelty of the study. There are considerable research works devoted to Hardy's issues in folklore and resistance (J. Dillion), different approaches to fiction (D. Kramer, A. Jackson, K. Ireland), creativity, scripture manners and rural paintings (S. Gatrell, J. Peck, K. Wilson, M. Williams, D. Cecil), imagination, fiction in psychological aspect (B. Hardy, R. Sumner), literary life (J. Gibson, F. Pinion, M. Millgate, H. Bloom, G. Harvey, D. Brown), interviews and recollections (J. Gibson, J. Sutherland), the connection of creative work and history (F. Reid, J. Bownas), and accordingly critical works that envisage literary heritage, biography, nationalcultural dimensions and conceptology in the works of I. NechuiLevytskyi (I. Denysiuk, M. Tarnavskyi, I. Koliada, V. Tkachenko, O. Tereshchenko, V. Vlasenko, V. Kononenko), and also principle transformation of portrait characterization (K. Sizov). Although the study of T. Hardy and I. Nechui-Levytskyi's prose has significant achievements, but a comprehensive study in character typification in a comparative aspect still does not exist. The proposed approach, the involvement of comparative and typological analysis allows us to identify both common basic aesthetic guidelines of the literature of realism, and typological differences determined by specifics of ethnocultural mentality.

The purpose of the article is to consider the aspect of characterization, determine the typology of this process on the example of T. Hardy and I. Nechui-Levytskyi's prose, make a comparative analysis of the works "Jude the Obscure" by T. Hardy and "Mykola Dzheria" by I. Nechui-Levytskyi, highlight the structural dominants of education, the source of which is the life of people and individual, spiritual world, as well as to analyze the life of the lyrical hero, the formation of his character, and the emergence of his main life landmarks. 
Main material. The main features of character typing cover the worldview of writers, their philosophical, aesthetic, ethical and religious views. Individual details which are manifested in actions, behavior, circumstances, create a multifaceted world of literary characters. In both works "Jude the Obscure" by T. Hardy and "Mykola Dzheria" by I. Nechui-Levytskyi, we meet the versatility of Jude Fawley and Mykola Dzheria's characters. This technique allows readers to consider the complex structure of these characters, from the standpoint of a detailed analysis of emotional experiences and psychological problems that reveal the characters of both protagonists.

Describing the character traits of Jude, Thomas Hardy emphasizes that he could never offend anyone, he was an intelligent, educated, sentimental man. Jude never responded to evil with evil, just the opposite. "Though Farmer Troutham had just hurt him, he was a boy who could not himself bear to hurt anything" [2, p. 13]. The author even emphasizes that Jude inherited his character. "But, oh no - poor or'nary child - there never was any sprawl on thy side of the family, and never will be" [2, p. 14]. However, the public environment decided the fate of Jude in its own way. A Jacqueline Dillion quoted: "Instinct, artificially suppressed by civilisation, is the cause of degeneration not only for Jude, but for 'thousands of young men' like him" [3, p. 158].

As for I. Nechui-Levytskyi, his literary activity opens new ways of artistic cognition of reality. In his work, psychological analysis becomes the main tool of artistic study of reality, leading to great epic forms, the transition from broad objective, descriptive, social and analytical paintings, to the analysis of characters' formation in close connection with circumstances. Oleksandr Biletskyi quite aptly notes that Mykola Dzheria - "це реальний борець проти соціальної несправедливості, проти гнобителів трудового народу на різних етапах його історичного існування" [4, p. 466].

I. Nechui-Levytskyi depicts everyday life of people, characterizing their social groups. As Ihor Koliada and Oleksandr Tereshchenko point out, the work "Mykola Dzheria" is presented to us as "образ українського селянина - шукача волі та правди" [5, p. 172]. Mykola was quite a gifted man. He was a "handyman", a master of all trades. He loved to play the violin. "Ще малим хлопцем він зробив маленьку скрипочку й сам вивчився грати козачка" [6, p. 40]. Mykola was musically endowed, he liked to perform various musical compositions, which were funny and sad. When Mykola became a musician, he "купив собі недорогу скрипку, підслухав усяких пісень у других музик і часто грав до танців дівчатам та хлопцям" [6, p. 40].

The author uses the violin to reveal the mood of his characters. As an example: "Микола направив струни, повів смичком і жалібна пісня розляглася по хаті. Він почав веселого козачка, а сам смичок знов повернув на жалібну думу. Мати слухала, слухала та й сама зажурилась" [6, p. 40]. The author reveals music as an integral part of Mykola's life. With the help of descriptions of musical rhythms in the work, we can identify various inherent social and cultural functions that they play, namely the magical, suggestive, spiritual and cathartic.

Then the author aptly describes the night sky, and with the help of a natural image of the sky reveals the state of protagonist's mind. "Він лежав лицем просто неба й дививсь на темне небо, засіяне зорями, ніби чорне поле пшеницею" [6, p. 40]. When the reader comes across a description of black earth, arable land, he imagines the black state of Mykola's soul. "Вечip був темний, теплий та тихий. Кругом стояли верби, груші та вишні, мов вироблені з каменя, а над вербами розстелялось глибоке темне небо" [6, p. 40]. The dark sky is protagonist's bad mood, gloomy sad thoughts that penetrated his soul, and the stone trees express his stony heart, hardened by social foundations. Here we saw that I. Nechui-Levytskyi reveals the character of Mykola in relation to the surrounding reality, nature, and social events.

T. Hardy also addresses a similar description of the combination of something living with a stone, only its description has a slightly different meaning. At the first meeting with Arabella, the reader can reveal how Jude looked at her: "He gazed from her eyes to her mouth, thence to her bosom, and to her full round naked arms, wet, mottled with the chill of the water, and firm as marble" [2, p. 45]. The author describes Arabella's body comparing it to marble, emphasizing its purity, beauty, youth, but coldness. After all, as it turned out later, Arabella was with a cold stone soul, a person who did not sympathize with anyone, a person who coldly perceived everything around.

With the help of artistic images T. Hardy depicts not only the character of Jude, but also Arabella's, emphasizing her type of behavior and revealing her inner essence. Let's take, for example, the scene with a cochin's egg that Arabella hatched in her bosom. Arabella explains the reason for this in such a way: "I am hatching a very rare sort. I carry it about everywhere with me, and it will get hatched in less than three weeks" [2, p. 63]. And when Jude asked where she was carrying that egg, "she put her hand into her bosom and drew out the egg, which was wrapped in wool, outside it being a piece of pig's bladder, in case of accidents. Having exhibited it to him she put it back" [2, p. 63]. According to Ivan Ohiienko, even during the pre-Christian beliefs, the egg represented "джерело зародження, як і сонце, чому воно з глибокої давнини стало емблемою сонця й шанувалося" [7, p. 26-27]. It is this subcontent that the author reveals further from the words of Arabella: "It's an old custom. I suppose it is natural for a woman to want to bring live things into the world" [2, p. 63].

Both writers quite aptly use such means of typification as actions, deeds, dialogues, monologues and portrait characteristics. Hardy portrays his character as an honest, responsible man who will not leave anyone in trouble, and is always responsible for his actions. For example, let's depict the scene where Arabella tells Jude that she is pregnant. Jude tells her in return: "Of course I never dreamt six months ago, or even three, of marrying. It is a complete smashing up of my plans - I mean my plans before I knew you, my dear. But what are they, after all! Dreams about books, and degrees, and impossible fellowships, and all that. Certainly we'll marry: we must!" [2, p. 66]. Jude is the person who is ready to take responsibility for what he has done at any moment. Deep down, he was very worried, because he understood what kind of wife Arabella will be. He blamed himself for how far his relationships with her had gone, and he had to take responsibility for the consequences. This was followed by the wedding of Jude and Arabella in the church, the oath at the altar. The author even describes the bride-cake of Fawley's aunt.

In "The life of Thomas Hardy 1840-1928" by Florence Emily Hardy where we can envisage the materials compiled largely from contemporary notes, letters, diaries, and biographical memoranda, as well as from oral information in conversations extending over many years, we came across an accurate quote that Swinburne wrote to Hardy after reading "Jude the Obscure": "The tragedy - if 
1 may venture an opinion - is equally beautiful and terrible in its pathos. The beauty, the terror, and the truth, are all yours and yours alone" [8, p. 270]. These words can even summarize the fate of main character. Although Jude had some pleasant moments in his life, in the end his life ended tragically.

I. Nechui-Levytskyi described the wedding ceremonies in some detail, namely the preparation of old Dzheria, Mykola's father, wedding clothes of Nymydora. "В неділю після вінчання йшла 3 церкви Нимидора в квітках, в стрічках, 3 вишиваним рушником у руці, весела й щаслива" [6, p. 50]. The author could not fail to mention the wedding bridesmaids and songs. In general, the Ukrainian people have long been famous all over the world for their beautiful songs. Ivan Ohiienko emphasizes that Ukrainian song is "не тільки високохудожня й високо мелодійна, але завжди глибоко змістовна, пристойна, навчальна” [9, p. 49-50]. It is the Ukrainian song that has long been under the great influence of the church, and "завжди веселить людське серце й потішає душу. I не тільки тішить душу, але й бадьорить іiі й підносить до неба. Гарна пісня очищує й гартує нам духа" [9, p. 50]. Ivan Ohiienko, being proud of Ukrainian singing, adds more: "Пісня - це душа народу, пісня - це щира розмова душі з серцем, i тому-то рідна пісня так мила нашому серцю та нашій душі” $[9$, p. 50].

As in the work of T. Hardy, I. Nechui-Levytskyi mentions the ceremonial wedding bread and other ceremonial elements too. "Після обіду в Нимидориного дядька на застеленому столі стояло соснове гільце, обквітчане колосками вівса, калиною та барвінком. На столі лежав здоровий коровай, обтиканий голубами, позолоченими сухозліткою; кругом короваю лежали шишки" [6, p. 50]. With the help of these rituals, the author tries to convey to the reader the love of Ukrainian people to their culture and traditions. If people preserve their culture, they preserve their nation. Maksym Tarnavskyi writes that considering the creative manners of I. Nechui-Levytskyi, it should be taken into account that "відданість своій нації займає центральне місце у його творчості" [10, p. 276].

Then each author describes the post-wedding stage, revealing the typification of characters more deeply. Jude's first disappointment was when he saw how Arabella undresses: "A long tail of hair, which Arabella wore twisted up in an enormous knob at the back of her head, was deliberately unfastened, stroked out, and hung upon the looking-glass which he had bought her" $[2, \mathrm{p} .68]$. The second disappointment was when she started telling the reasons why she began to wear strange hair: "In town the men expect more, and when I was barmaid at Aldbrickham" [2, p. 68]. Even the beginning of her story embarrassed Jude, but despite this, Arabella continued: "Well, not exactly barmaid - I used to draw the drink at a public-house there - just for a little time; that was all. Some people put me up to getting this, and I bought it just for a fancy. The more you have the better in Aldbrickham, which is a finer town than all your Christminsters. Every lady of position wears false hair - the barber's assistant told me so" [2, p. 68]. The third moment was when he noticed Arabella pulling in her cheeks, trying to depict seductive dimples. However, the key was her confession that she was not pregnant, which depressed Jude in general and distorted the essence of their marriage. If this truth had been revealed earlier, before the wedding, then Jude's life and destiny in general might have turned out differently. Selfcharacterization plays a big role in creating Jude's character. We often learn about thoughts, experiences, inner state of the hero not only from monologues, dialogues, but also from facial expressions, gestures and expressions of his eyes.

An important means of typification in the works of T. Hardy and I. Nechui-Levytskyi is not only the portrait individualization, but also the language of characters. Each author aptly uses his own vocabulary, specific to people, conveys a certain sentence structure and intonation. In typifying characters, I. Nechui-Levytskyi turns to various images, using various artistic details. For example, we encounter visual details when the author, describing how Nymydora returned from a meeting with Mykola to Kavunykha's house, saw that the door was closed. She climbed into the house through the tower. In the description, the author compares Nymydora with a goat: "Легко й прудко, як та коза, вона вхопилась за кінець сволока, вискочила на сволок і крадькома полізла на горище" [6, p. 46]. I. Nechui-Levytskyi also uses sound details, for example, we can quote how Osavula summoned the people to serfdom. He shouted over Mykola's head, without taking off his hat or greeting people. At that moment, Mykola thought: "А бодай тобі заціпило! Кричить, мов скажений, наче нам позакладало вуха!" [6, p. 38]. Or, conversely, let's take the positive point when the author compares the singing of girls with bird singing: "Як тільки Микола пристав до дівчат, всі дівчата заразом так і заспівали пісні, мов пташки весною. Разом $з$ дівчатами заспівала й Нимидора" [6, p. 42]. Mykola was so fond of Nymydora's voice that joy and happiness poured into his heart that he did not see the path under his feet. "Йому здалося, що разом з Нимидорою заспівала калина, заспівало синє небо" [6, p. 42]. Let's envisage psychological details: "В хату ввійшов старий Джеря, високий, тонкий, 3 сивуватими довгими вусами, 3 нужденним блідим лицем та смутними очима" [6, p. 40]. The acquaintance with Mykola's father is psychologically rich. From here the reader understands that this person looked so because of hard work. "Глибокі зморшки на щоках, на лобі, поморщена темна потилиця од гарячого сонця, грубі руки - все це ніби казало, що йому важко жилося на світі" $[6, p .40]$. Based on this analysis, we see that literary activity of I. Nechui-Levytskyi opens new ways of artistic cognition of reality, where the main tool is psychological analysis. In the work "Mykola Dzheria" the leading descriptive form becomes epic, because the author focuses on the analysis of characters' formation in close connection with life circumstances.

Conclusions. Decisive methods for understanding the characters in T. Hardy and I. Nechui-Levytskyi's works are the relationships between socially and personally meaningful values. Regarding the typological coincidences in both works, it was noticeable that both authors in depicting the typification of characters portrayed the possession of characters' goals in life, their purposefulness, which left a huge imprint on all behavior throughout the plots. The authors pictured in both characters something dominant, to which the characters purposefully went. This is what added to the features of their characters some peculiar colors. However, there is a big difference between two literary characters, because the authors portrayed them in a slightly different way, with distinctive features, characteristics and peculiarities. Each protagonist was depicted in a different perspective, with its own specific set of mental traits. Each character was portrayed with a certain individual approach and at the same time generalized certain life types of people, their culture, which reflected the subject of author's knowledge. 


\section{References:}

1. Павлик Н.В. Психологія гармонізації характеру в юнацькому віці: Монографія. К.: Логос, 2015. 383 с.

2. Hardy T. Jude the Obscure. London : Penguin Popular Classics, 1994. $498 \mathrm{p}$.

3. Dillion J. Thomas Hardy: Folklore and Resistance. London : Macmillan Publishers Ltd., 2016. 206 p.

4. Білецький О. Українська література серед інших літератур світу. Сучасна літературна компаративістика: стратегії і методи. Антологія / За заг. ред. Дмитра Наливайка. Київ : Вид. дім «Києво-Могилянська академія», 2009. С. 433-473.

5. Коляда I. «Вічний бурлака нашої літератури». Іван Нечуй-Левицький. Життєпис. Національно-культурний вимір : монографія / Ігор Коляда, Володимир Ткаченко, Олександр Терещенко. Харків : Вид-во «Ранок», 2019. 448 с.

6. Нечуй-Левицький I.C. Микола Джеря. Зібрання творів : у 10 т. Київ : Наукова думка, 1968. Т. 3. С. 34-142.

7. Іларіон, митрополит. Дохристиянські вірування українського народу : іст.-реліг. монографія. Київ : АТ «Обереги», 1992. 424 с.

8. Hardy F.E. The Life of Thomas Hardy 1840-1928. London, Basingstoke : The Macmillan Press Ltd, 1983. 470 p.

9. Огієнко I. Наша літературна мова. Київ : Наша культура і наука, 2011. $356 \mathrm{c}$

10. Тарнавський М. Нечуваний Нечуй. Реалізм в українській літературі. К. : Лаурус; Торонто : Наук. т-во ім. Тараса Шевченка в Канаді, 2016. 289 c.

Крук А. А. Типізація характерів у прозі Т. Гарді та І. Нечуя-Левицького

Анотація. У статті на матеріалі прозових творів «Джуд Непримітний» Т. Гарді та «Микола Джеря» I. Нечуя-Левицького розкривається сукупність психологічних властивостей, з яких складаються образи літературних персонажів. На тлі з'ясування стильових, жанрово-композиційних, мовно-образних особливостей прози Т. Гарді, I. НечуяЛевицького окреслюються авторські зображення характерів головних героїв Джуда Фаулі та Миколи Джері, що лежать в основі епічного мислення другої половини XIX ст. Завдяки детальному текстуальному аналізу виділяються ідейно-естетичні риси художніх образів протагоністів кожного прозаїка, досліджуються особливості творчої манери видатних митців.

Загалом особливості типізації залежать від світогляду письменників, включаючи їхні філософські, естетичні, етичні та релігійні погляди на світ. На типізації позначаються саме такі особливості, як переконання, принципи пізнання й ідеали письменників. У характеристиці персонажів Т. Гарді та I. Нечуя-Левицького значну роль відіграє портрет. Часто зовнішність героя дає уявлення про такі особливості характеру, як вдача, смаки, уподобання. Іноді портретна характеристика взагалі виступає справжнім дзеркалом душі. Досить часто автори індивідуалізують портрети своїх головних героїв.

Обидва письменники досить влучно використовують такі засоби типізації, як дії, вчинки, діалоги, монологи, авторську розповідь, портрети своїх персонажів. Проте у творі Томаса Гарді під час створення характеру Джуда велику роль відіграла самохарактеристика. Про думки, переживання, внутрішній стан героя часто довідуємося iз монологів, діалогів, а також з міміки, жестів та виразу очей. Що ж до типізації характеру головного героя I. Нечуя-Левицького, то помітним є те, що автор звертається до різноманітних образів, використовуючи такі художні деталі, як зорові, звукові, а також психологічних аналіз. Іншим, не менш важливим засобом типізації в творах Т. Гарді та I. Нечуя-Левицького виступає мова героїв, влучне використання лексики, культурних традицій та звичаїв, притаманних своєму народові.

Кожен образ було окреслено 3 достатньою повнотою та індивідуальною конкретністю. Така типізація характерів допомагає відчитати не лише історично зумовлений тип поведінки персонажів, але й морально-естетичну концепцію людського буття загалом.

Ключові слова: психологічний аналіз, світогляд, художнє пізнання, опис, образ. 